\title{
Conserving Urban Wildlife in the Face of Climate Change ${ }^{1}$
}

\section{Daniel Feinberg and Mark Hostetler ${ }^{2}$}

\section{Introduction}

In recent years, climate change has become prominent in the public eye. News outlets share photographs of polar bears on melting ice, while movies show charts of increasing global temperatures. What do these images mean? With air pollution, the world is heating up at a startling pace. In just 200 years since the Industrial Revolution, average temperatures have increased more rapidly than in the previous 11,000 years.

Virtually all climatologists agree that humans are increasing the rate of the Earth's warming by releasing greenhouse gases into the atmosphere (Anderegg et al. 2010). This process occurs largely through the burning of coal, petroleum, and natural gas, known collectively as fossil fuels. Burning fossil fuels causes carbon dioxide $\left(\mathrm{CO}_{2}\right)$ gas to build up in the Earth's atmosphere, where it causes warming by trapping the sun's rays. $\mathrm{CO}_{2}$ can originate from many different sources. Most people think of factories and cars, but you might be surprised to learn that houses and residential neighborhoods are also sources of carbon because the energy that powers stoves, air conditioners, and everything else in a house that runs on electricity or gas is often derived from burning fossil fuels.

This article describes the connections between climate change, wildlife, and human neighborhoods and presents several ways for residents to live more sustainably. The article addresses three interrelated topics: (1) how residential neighborhoods contribute to climate change through $\mathrm{CO}_{2}$ emissions, (2) how climate change affects plants and animals that live in and around urbanized areas, and (3) what residents can do to help conserve these plants and animals both by managing urban areas and by reducing household carbon emissions.

\section{How Neighborhoods Contribute to Climate Change}

Many aspects of domestic life contribute to a household's "carbon footprint," a term that refers to the total amount of $\mathrm{CO}_{2}$ that the household emits from all of its carbon sources combined. Often these sources include the basic activities that make homes livable (heating, cooling, consuming water, disposing of waste) because these activities require energy, and that energy typically comes from the burning of fossil fuels (Jones and Kammen 2011). Outside of the house itself, landscaping can also contribute to the household carbon footprint. Mowing a lawn, for instance, requires an energy source, and burning fuel to obtain that energy adds $\mathrm{CO}_{2}$ to the atmosphere.

If the abundance of carbon sources seems overwhelming, it is important to keep in mind that there are also carbon sinks-structures that take in and store some of the carbon that the various sources have released. Plants can serve as carbon sinks through the chemical reaction of photosynthesis, wherein the plants convert $\mathrm{CO}_{2}$ into sugar,

1. This document is WEC336, one of a series of the Wildlife Ecology and Conservation Department, UF/IFAS Extension. Original publication date September 2013. Visit the EDIS website at http://edis.ifas.ufl.edu.

2. Daniel Feinberg, graduate student, Department of Wildlife Ecology and Conservation; and Mark Hostetler, professor and Extension specialist, Department of Wildlife Ecology and Conservation, UF/IFAS Extension, Gainesville, Florida, 32611-0430 
with sunlight as their energy source. Furthermore, trees can provide shade that helps to cool houses and reduces the need for air-conditioning. If an air conditioner is running less, then the household is consuming less energy. For these reasons, trees and other plants can reduce a household's carbon footprint.

\section{How Climate Change and Urbanization Impact Wildlife}

Individually, climate change and urbanization threaten wildlife populations, and together, they can interact in ways that present additional threats. This section focuses on two types of interactions in which climate change and urbanization can harm wildlife. The first interaction occurs between severe weather events and nitrate pollution, and the second occurs between sea level rise and development.

The dual threats of climate change and urbanization can increase the input of nitrates into water bodies (Kaushal et al. 2008). Nitrates $\left(\mathrm{NO}_{3}\right)$ are chemicals that are prevalent in fertilizer, and excess $\mathrm{NO}_{3}$ from fertilizer can travel to rivers and lakes via storm runoff or groundwater flow. People typically use fertilizers on lawns and landscaped areas, and after a rain event, adjacent pavement and other impervious surfaces prevent the absorption of $\mathrm{NO}_{3}$ into the soil and vegetation. $\mathrm{NO}_{3}$ runs into gutters and storm drains and can be carried by stormwater directly into nearby bodies of water, where it can over-nourish the water and cause algal blooms (Figure 1). The algal blooms then use up most of the oxygen in the water, creating hypoxic (low-oxygen) conditions that cause fish and other animals to suffocate and die. The algae can also block out sunlight, making it impossible for plants to grow. Thus, the use of fertilizers combined with impervious surfaces in urban areas can severely impact the animals and plants in nearby bodies of water.

Where does climate change fit in? Recall two of the worst catastrophes of recent years: Hurricane Katrina in New Orleans and Superstorm Sandy in the northeastern United States. With climate change, storms of this magnitude are predicted to become commonplace in the years to come (Freedman 2013). In addition to tragic loss of human life and property, severe weather events can destroy ecological communities by triggering the release of $\mathrm{NO}_{3}$ in sudden bursts and causing it to flow from urban areas into nearby rivers and lakes. The subsequent algal blooms block out sunlight and kill aquatic wildlife by creating hypoxic conditions. Additionally, climate change can result in higher water temperatures, which facilitate more algal growth and exacerbate the damage to wetlands.

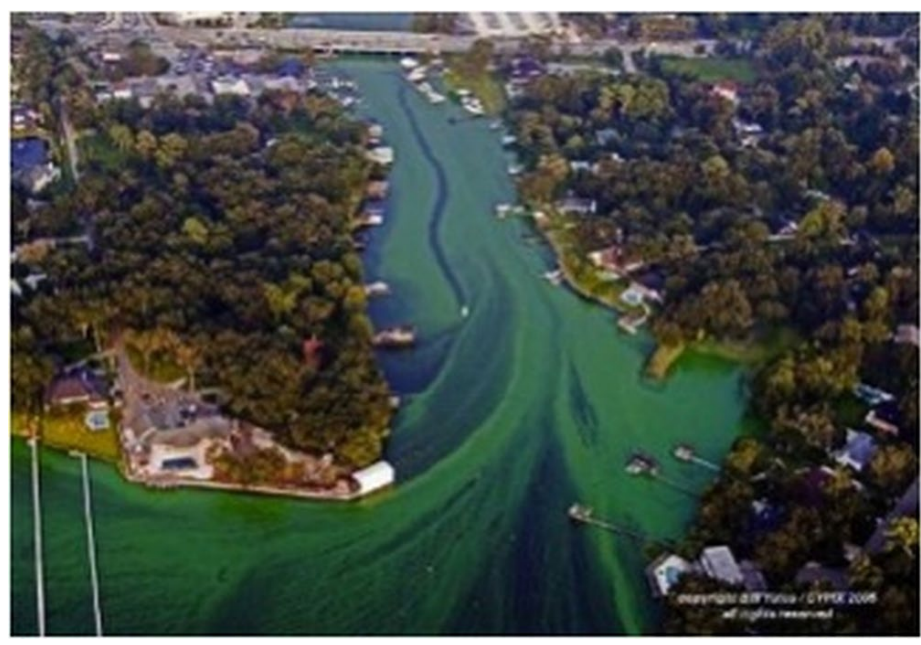

Figure 1. Algal blooms in the St. Johns River, Florida. Runoff from nearby lawns and agricultural areas can carry excessive fertilizer to water bodies and create algal blooms.

Credits: Bill Yates, CYPIX (courtesy of Pierce Jones)

Climate change combined with urban development reduces coastal habitat for wildlife. Sea level rise is a consequence of climate change because the planet's oceans are rising in proportion to global changes in temperature (Rahmstorf 2007). Various factors contribute to this trend: hotter temperatures cause glaciers and ice sheets to melt, adding water to the oceans, and the physical properties of water cause it to expand and take up more space when it is warmer. As the oceans get higher, they will wipe out coastal habitats, which are already scarce because people construct houses and buildings along the coast.

The Lower Keys marsh rabbit is a victim of this phenomenon. As an endangered species in Florida, the Lower Keys marsh rabbit is particularly sensitive to changes in coastal habitat (U.S. Fish and Wildlife Service 1994). Rising water threatens to engulf coastal marshes and push the rabbit inland, where the marshes have already given way to roads, buildings, and walls (Schmidt et al. 2012). Thus, the combination of sea level rise and coastal development is likely to leave very little natural habitat where the Lower Keys marsh rabbit could live.

Many other animals face the same predicament as the Lower Keys marsh rabbit. For example, certain types of birds, such as the snowy plover, are also running out of places to live as a result of urban development and sea level rise. In Florida, the snowy plover can only breed in a very specific type of habitat that contains undisturbed sand dunes (Lamonte et al. 2006), which face the same squeezing effects as the rabbit's marsh habitat. As sea level continues to come up, the water pushes plovers towards 
urban developments that do not contain sand dunes and, therefore, are not suitable for the birds' survival and breeding. Models predict that the decline of plover populations will occur even more quickly than the disappearance of their habitat (Aiello-Lammens et al. 2011).

\section{How Homeowners Can Conserve Wildlife Habitat}

Although climate change and urbanization pose serious threats to wildlife habitat, homeowners can make a positive impact through two basic approaches: directly protecting habitat in urban areas and reducing carbon emissions. Stewardship of urban and suburban habitat patches can conserve plants and animals, and smaller household carbon footprints can help to slow the pace of climate change and reduce its effects on wildlife.

\section{Directly Protecting Habitat}

Through simple actions, homeowners can conserve wildlife habitat in their communities. One of the most effective actions is to landscape yards with native plants, which can provide habitat for animals (Figure 2), especially if the houses are located near natural areas (Hostetler and Drake 2009; Hostetler and Knowles-Yanez 2003). Homeowners in Florida can learn about how to select native plants by visiting the Florida-Friendly Landscaping site.

If yards contain invasive exotic plants, these plants can spread to nearby natural areas and make them less hospitable for native plants and animals (Hostetler et al. 2011). Through a process called allelopathy, some exotic plants release deadly chemicals from their roots into the soil (Bais et al 2003). These chemicals prevent other plants from growing in the area. Furthermore, exotic plants have a knack for outcompeting native plants for nutrients and often avoid being eaten by native animals (Callaway and Aschehoug 2000). Homeowners can help to avoid these situations by removing invasive exotic plants and by landscaping with native species.

Another important homeowner action is to decrease the use of fertilizer to a level that is appropriate for a particular lawn (calculate this level online). By using less fertilizer on their lawns (exactly the amount of fertilizer that the grass needs but no more than it can absorb), homeowners can reduce the pollution of nearby rivers and streams and help to prevent algal blooms.

Also, residents can minimize the impacts of pets on wildlife by keeping them indoors or on leashes. If dogs and cats are

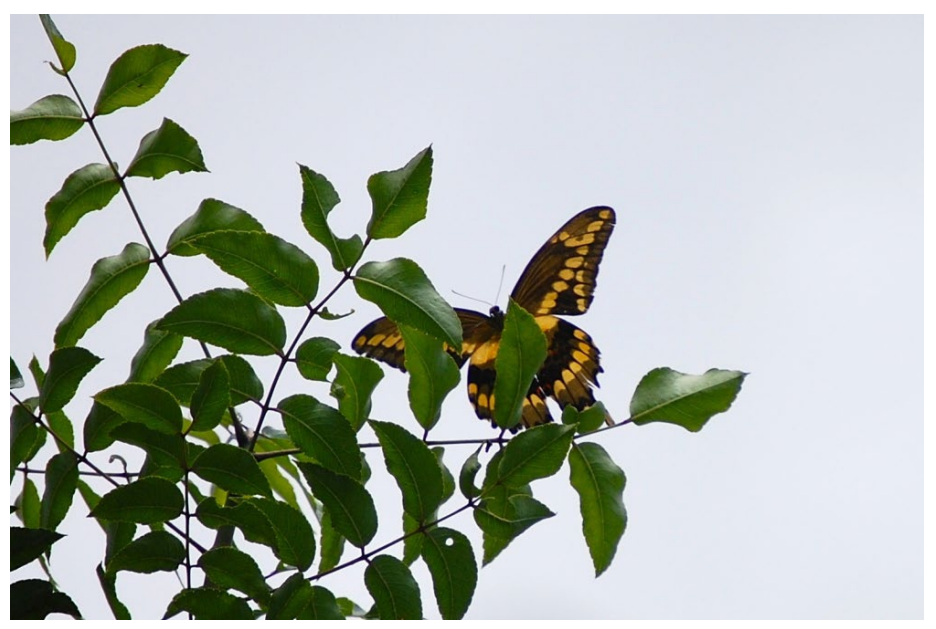

Figure 2. Homeowners can landscape their yards in ways that provide habitat for animals, such as this butterfly in the Madera green neighborhood in Gainesville, FL.

Credits: Daniel Feinberg

allowed to roam freely throughout a neighborhood, they can pollute the natural areas with their droppings and can kill birds and other wild animals (Baker et al. 2005; Beckerman et al. 2007). Outdoor cats have even been known to kill endangered species such as the Florida Anastasia beach mouse (Bird et al. 2002). These deaths could be prevented if people kept their pets indoors or on leashes.

\section{Reducing Carbon Emissions}

Homeowners can further help wildlife by shrinking their household carbon footprint, thereby reducing their contribution to climate change. This reduction can take many forms, all of which fall under two categories: releasing less $\mathrm{CO}_{2}$ (minimizing carbon sources), and taking up more of the existing $\mathrm{CO}_{2}$ (maximizing carbon sinks).

The following examples represent some of the approaches that homeowners can take:

- Ways to minimize carbon sources

1. Make homes more energy-efficient

2. Eat locally grown food

3. Reduce lawn maintenance

4. Use cold water for laundry

5. Carpool

- Ways to maximize carbon sinks

1.Plant trees

2. Leave natural green spaces 


\section{Additional Resources}

The following lists include some of the other sources of information regarding climate change, urban wildlife, and sustainability.

\section{Online Resources}

Bird, B. L., L. C. Branch, and M. E. Hostetler. 2002. "Beach Mice." EDIS \#WEC165, http://edis.ifas.ufl.edu/uw173

Escobedo, F., J. A. Seitz, and W. Zipperer. 2009. "Carbon Sequestration and Storage by Gainesville's Urban Forest." EDIS \#FOR210, http://edis.ifas.ufl.edu/fr272

Florida-Friendly Landscaping: The Smart Way to Grow. http://www.floridayards.org/

Freedman, A. 2013. "Storm Surge Risk Amplified by Climate Change, Study Finds." Huffington Post. http:// www.huffingtonpost.com/2013/03/18/storm-surgerisk_n_2902823.html

Harmony Florida. 2013. "Sustainable Foods." http://www. harmonyfl.com/sustainable-food

Harvey, R. G., L. A. Brandt, and F. J. Mazzotti. 2012. "Climate Change Adaptation: New Perspectives for Natural Resource Management and Conservation." EDIS \#WEC318, http://edis.ifas.ufl.edu/uw363

Havens, K. 2012. "Effects of Climate Change on the Eutrophication of Lakes and Estuaries." EDIS \#SGEF-189. http:// edis.ifas.ufl.edu/sg127

Havens, K., and T. Frazer. 2012. "Rethinking the Role of Nitrogen and Phosphorus in the Eutrophication of Aquatic Ecosystems." EDIS \#SGEF190. http://edis.ifas.ufl.edu/sg118

Hostetler, M., and F. Escobedo. 2010. "What Types of Urban Greenspace Are Better for Carbon Dioxide Sequestration?" EDIS \#WEC279, http://edis.ifas.ufl.edu/uw324

Plait, P. 2013. "The Earth is Warming Faster Now Than it Has in 11,000 Years." Slate. http://www.slate.com/blogs/ bad_astronomy/2013/03/13/global_warming_new_study_ shows_warming_is_faster_than_it_has_been_in_11.html

Taylor, N. W., M. J. Kipp, and K. C. Ruppert. 2008. "Energy Efficient Homes: Incentive Programs for Energy Efficiency." EDIS \#FCS3268, http://edis.ifas.ufl.edu/fy1033

Trenholm, L. E., and J. B. Unruh. 2003. "Figuring out Fertilizer for the Home Lawn.” EDIS \#ENH962, http://ufdc. ufl.edu/IR00003315/00001
Vaughn, R., M. Hostetler, and F. Escobedo. 2012. “Conservation Subdivision: Post-Construction Phase - Urban Trees Can Reduce Household Carbon Footprint." EDIS \#WEC321, http://edis.ifas.ufl.edu/uw366

\section{Scientific Publications}

Aiello-Lammens, M. E., M. L. Chu-Agor, M. Convertino, R. A. Fischer, I. Linkov, and H. R. Akcakaya. 2011. "The impact of sea-level rise on Snowy Plovers in Florida: integrating geomorphological, habitat, and metapopulation models." Global Change Biology 17(12): 3644-3654.

Anderegg, W. R. L., J. W. Prall, J. Harold, and S. H. Schneider. 2010. "Expert credibility in climate change." PNAS 107(27): 12107-9.

Bais, H. P., R. Vepachedu, S. Gilroy, R. M. Callaway, and J. M. Vivanco. 2003. "Allelopathy and exotic plant invasion: from molecules and genes to species interactions." Science 301(5638): 1377-1380.

Baker, P. J., A. J. Bentley, R. J. Ansell, and S. Harris. 2005. "Impact of predation on domestic cats (Felis catus) in an urban area." Mammal Rev. 35: 302-312.

Beckerman, A. P., M. Boots, and K. J. Gaston. 2007. "Urban bird declines and the fear of cats." Anim. Conserv. 10: 320-325.

Callaway, R. M., and E. T. Aschehoug. 2000. "Invasive plants versus their old and new neighbors: a mechanism for exotic invasion." Science 290(5491): 521-523.

Hostetler, M., and D. Drake. 2009. "Conservation subdivisions: A wildlife perspective." Landscape and Urban Planning 90: 95-101.

Lamonte, K. M., N. J. Douglass, J. G. Himes, and G. E. Wallace. 2006. Status and distribution of the snowy plover in Florida. 2002 Study Final Report. Florida Fish and Wildlife Conservation Commission, Tallahassee, Florida.

Rahmstorf, S. 2007. "A semi-empirical approach to projecting future sea-level rise." Science 315(5810): 368-370.

Schmidt, J. A., R. McCleery, J. R. Seavey, S. E. Cameron Devitt, and P. M. Schmidt. 2012. "Impacts of a half century of sea-level rise and development on an endangered mammal." Global Change Biology 18: 3536-3542.

U.S. Fish and Wildlife Service. 1994. Recovery Plan for the Lower Keys marsh rabbit. Retrieved from http://www.fws. gov/verobeach/MSRPPDFs/LowerKeysRabbit.pdf 